\title{
ANALISIS BURN UP PADA REAKTOR CEPAT BERPENDINGIN GAS MENGGUNAKAN BAHAN BAKAR URANIUM ALAM
}

\author{
Feriska Handayani Irka ${ }^{(1)}$, Zaki Su'ud ${ }^{(2)}$ \\ (1) Jurusan Fisika FMIPA Universitas Andalas, Padang \\ (2) Jurusan Fisika, FMIPA Institut Teknologi Bandung, Bandung \\ Email: Feriska.irka@gmail.com
}

\begin{abstract}
Burn up analysis of gas cooled fast reactor (GCFR) with natural uranium fuel has been done. Burn up modification used in order to make reactor can be operated with natural uranium without enrichment. The reactor core subdivided into 10 regions with the same volume in radial directions. Optimization evaluated by burning natural uranium for 100 years and put each of its burn up result per year in reactor with certain configuration. After 10 years burn up period, fuel from first region was shuffling radially to second region and so on fuel from $9^{\text {th }}$ shuffling to $10^{\text {th }}$ and then fuel from $10^{\text {th }}$ was carried out from reactor core and fresh uranium input to the first region. Calculation has been done by using SRAC system code with JENDL-32 as library, with cylindrical two dimensional R-Z core models. Shuffling method was used in order to make reactor can be operated using natural uranium. . This natural uranium initially being burned by guessed power level of burn up. The height and diameter core are $350 \mathrm{~cm}$ and $240 \mathrm{~cm}$ respectively. The volume fraction for this design is $65 \%$ fuel, $10 \%$ cladding and $25 \%$ coolant; with output power $700 \mathrm{MWTh}$. The result show that reactor demonstrated excellent performance with effective multiplication factor 1,055 .
\end{abstract}

Keywords:GCFR, natural uranium, burn up, shuffling method

\begin{abstract}
ABSTRAK
Analisis burn up pada reaktor cepat berpendingin gas menggunakan bahan bakar uranium alamtelah dilakukan. Modifikasi sistem burn up dilakukan agar reaktor dapat beroperasi menggunakan bahan bakar uranium alam tanpa pengayaan. Teras reaktor dibagi menjadi 10 regiondengan volume sama secara radial. Awalnya uranium alam dibakar selama 100 tahun kemudian hasil burn up masing-masing tahun ditempatkan dalam teras reaktor dengan konfigurasi tertentu. Setelah 10 tahun periode burn up, bahan bakar dishuffling secara radial dari region $1 \mathrm{ke}$ region 2, begitu seterusnya sampai bahan bakar region 9 dishuffling ke region 10 sehingga bahan bakar region 10 di keluarkan dari teras reaktor dan bahan bakar baru di tempatkan di region 1 . Perhitungan dilakukan menggunakan sistem pengkodean SRAC dan JENDL-32 Library dengan model teras silinder 2D R-Z. Tinggi dan diameter teras aktif masing-masing $350 \mathrm{~cm}$ dan $240 \mathrm{~cm}$. Fraksi volume yang digunakan 65\% fuel, 10\% cladding , 25\% coolant; dengan daya keluaran 700 MWTh. Analisis neutronik dan burn up reaktor menunjukkan reaktor yang dirancang menunjukkan performa yang baik dengan nilai multiplikasi neutron (k-eff) 1,055
\end{abstract}

Kata kunci: GCFR, uranium alam, burn up, metode shuffling

\section{PENDAHULUAN}

Krisis energi di Indonesia membutuhkan jalan keluar berupa energi terbarukan, salah satunya energi nuklir. Energi nuklir telah mengalami perkembangan ke arah yang lebih baik dari generasi I sampai generasi IV yang sedang dirancang saat ini. Keunggulan generasi IV dibandingkan generasi sebelumnya meliputi pengurangan biaya pokok, keamanan nuklir yang dipertinggi, limbah nuklir yang diperkecil, dan pengurangan lebih lanjut dalam resiko pembuatan senjata (Driscoll and Heizler, 2005). Salah satu reaktor 
generasi IV yang sedang dikembangkan adalah reaktor cepat berpendingin gas, gas cooled fast reactor (GCFR). Dengan memodifikasi sistem burn up bahan bakar di dalam teras reaktor GCFR, dimungkinkan untuk menggunakan uranium alam sebagai bahan bakar reaktor. Modifikasi sistem burn up pada teras reaktor cepat sebelumnya telah pernah dilakukan. Suud (2013) melakukan modifikasi burn up pada teras reaktor cepat berpendingin gas secara axial,dengan input uranium alam tanpa pengayaan. Penelitian ini menunjukkan reaktor yang dirancang menunjukkan performa yang baik dengan rata-rata burn up sekitar 25,9\% HM. Rida (2008) melakukan studi desain reaktor cepat berpendingin $\mathrm{Pb}-\mathrm{Bi}$ berbasis uranium alam menggunakan strategi shuffling, yang menghasilkan reaktor yang dirancang dapat beroperasi selama 90 tahun dengan periode refueling 15 tahun memberikan hasil yang baik untuk perbandingan fraksi bahan bakar, cladding dan coolant sebesar 51\%:14\%:35\%. Pada penelitian ini dilakukan analisis burn up reaktor cepat berpndingin gas menggunakan input uranium alam dengan strategi shuffling arah radial.

\section{TINJAUAN PUSTAKA}

\subsection{Reaktor Cepat Berpendingin Gas (GCFR)}

GCFR merupakan salah satu dari reaktor generasi IV yang saat ini sedang dikembangkan dengan fitur spektrum neutron cepat dan beroperasi dengan sistem pembakaran tertutup (closed fuel cycle) seperti ditunjukkan pada gambar 1. Hal ini menguntungkan dari segi efisiensi konversi uranium fertil (U-238) dan manajemen aktinida. Proses pembakaran terjadi di dalam teras reaktor, panas yang dihasilkan oleh reaksi fisi di dalam teras reaktor ditransfer ke pembangkit uap, uap yang dihasilkan digunakan untuk memutar turbin yang dihubungkan dengan generator listrik dan akan menghasilkan listrik.

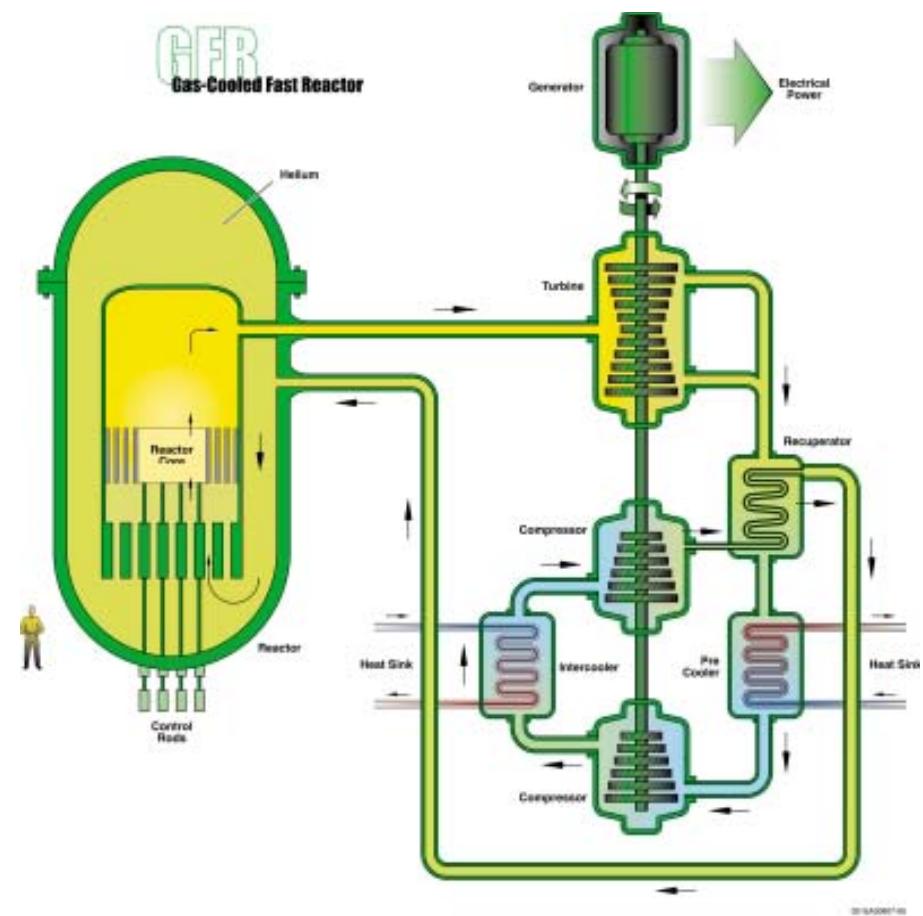

Gambar 1 Reaktor Cepat Berpendingin Gas (GCFR)

(http://www.oektg.at/bildungsarbeit/publikationen/generation-iv-gas-cooled-fast-reactor/) 


\subsection{Analisis Burn up}

Perhitungan dasar dalam manajemen bahan bakar adalah perhitungan penyusutan dan produksi isotop sebagai fungsi waktu. Persamaan laju reaksi yang menggambarkan densitas jumlah inti dalam teras dapat diperoleh dengan menggunakan prinsip keseimbangan yang sederhana. Andaikan $N_{A}(r, t)$ adalah densitas untuk nuklida jenis A, maka persamaan laju reaksi secara umum dapat digambarkan dalam skema berikut:

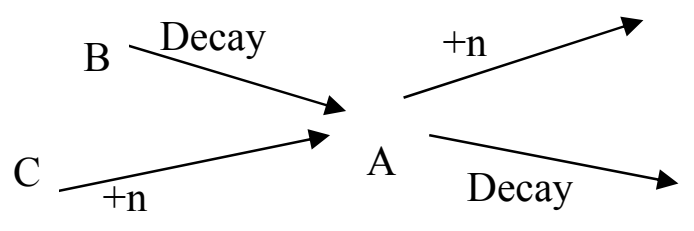

Gambar 2 Prinsip keseimbangan nuklida A.

Secara matematis skema tersebut dapat ditulis sebagai berikut (Walter and Reynolds, 1981):

$$
\frac{d N_{A}}{d t}=-\lambda_{A} N_{A}-\left[\sum_{g} \sigma_{a g}^{A} \varphi_{g}\right] N_{A}+\lambda_{B} N_{B}+\left[\sum_{g} \sigma_{\lambda g}^{C} \varphi_{g}\right] N_{C}
$$

dengan $\lambda_{A} N_{A}$ adalah bagian yang hilang karena peluruhan radioaktif nuklida $\mathrm{A}$, sedangkan $\left[\sum_{g} \sigma_{a g}^{A} \varphi_{g}\right] N_{A} \quad$ adalah bagian yang hilang karena tangkapan neutron oleh nuklida $\mathrm{A}, \lambda_{\mathrm{B}} N_{B}$ merupakan nuklida tambahan karena peluruhan dari nuklida B ke A dan $\left[\sum_{g} \sigma_{c g}^{C} \varphi_{g}\right] N_{C}$ merupakan perubahan dari nuklida $\mathrm{C}$ menjadi A melalui tangkapan neutron.

\section{DESAIN TERAS}

Spesifikasi umum desain reaktor yang digunakan dalam penelitian ini adalah sebagai berikut:

Tabel 1 Spesifikasi umum desain reaktor

\begin{tabular}{|l|l|}
\hline Parameter & Deskripsi \\
\hline Daya (MWth) & 700 \\
\hline Tipe pin cell & Cylinder cell \\
\hline Geometri teras & 2-D Cylinder \\
\hline Periode refueling & 10 \\
\hline Bahan bakar (fuel) & UN dan PuN \\
\hline Struktur (cladding) & $\mathrm{SS} 316$ \\
\hline Pendingin (coolant) & Helium \\
\hline Diameter Pin /pitch & $1,4 \mathrm{~cm}$ \\
\hline Tinggi teras aktif & $350 \mathrm{~cm}$ \\
\hline Diameter teras aktif & $240 \mathrm{~cm}$ \\
\hline
\end{tabular}


Uranium alam yang akan digunakan untuk bahan bakar reaktor terlebih dahulu dibakar dalam jangka waktu tertentu sehingga menghasilkan bahan bakar fisil yang dapat berfisi di dalam reaktor. Teras reaktor dibagi menjadi 10 bagian yang memiliki volume sama secara radial seperti terlihat pada gambar 3. Pada awal operasi reaktor, masing-masing region diisi dengan bahan bakar uranium alam. Setelah 10 tahun pembakaran, hasil burn up pada region 1 di shuffling ke region 2, hasil burn up region ke-2 di shuffling ke region 3 , begitu seterusnya sampai hasil burn up region ke-9 di shuffling ke region 10 dan hasil burn up region ke-10 dikeluarkan dari teras reaktor sehingga region 1 dapat diisi dengan bahan bakar baru (fresh fuel) seperti yang terlihat pada gambar 4. Begitu seterusnya sampai 100 tahun operasi reaktor.Uranium alam ini awalnya dibakar dengan power level burn up tebakan setiap dua tahun.

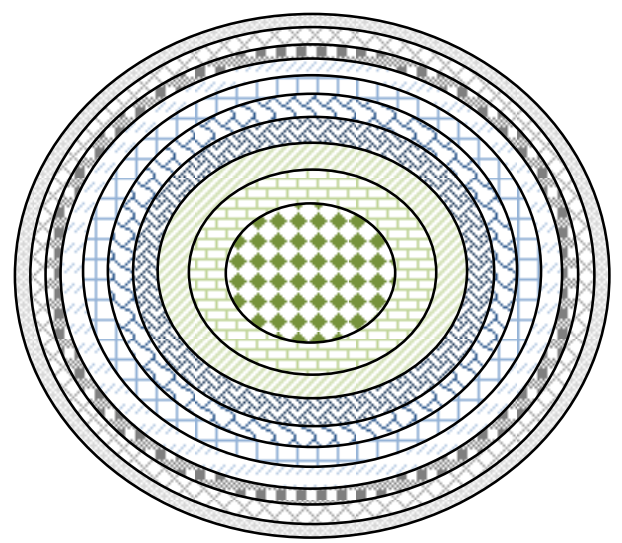

Gambar 3 Penampang lintang konfigurasi teras reaktor arah radial.

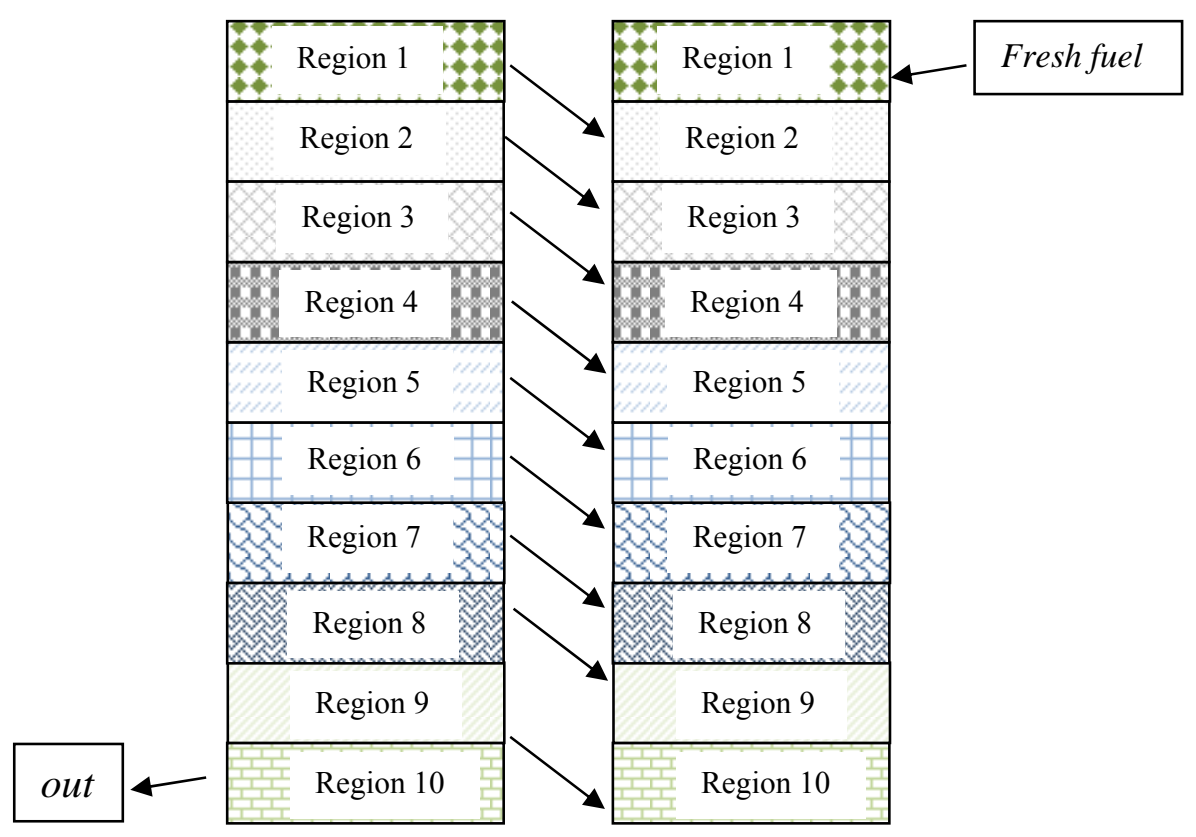

Gambar 4 Sistem shuffling arah radial 


\section{METODOLOGI PENELITIAN}

Perhitungan dan simulasi dalam penelitian ini menggunakan pemograman SRAC yang dikembangkan oleh oleh JAERI. Pada modul transport SRAC yang bernama PIJ dilakukan perhitungan homogenisasi sel dan mengerjakan perhitungan burn up sel. Rancangan awal untuk modul PIJ ini dilakukan tebakan untuk 50 nilai power distribusi (50 tahun periode burn up $\sim 100$ tahun operasi reaktor). Hasil yang didapatkan dari proses PIJ ini nantinya akan digunakan untuk perhitungan core (teras) reaktor pada modul CITATION, yang nantinya akan digunakan kembali pada modul PIJ. Secara keseluruhan proses perhitungan burn up diperlihatkan oleh gambar 5 .

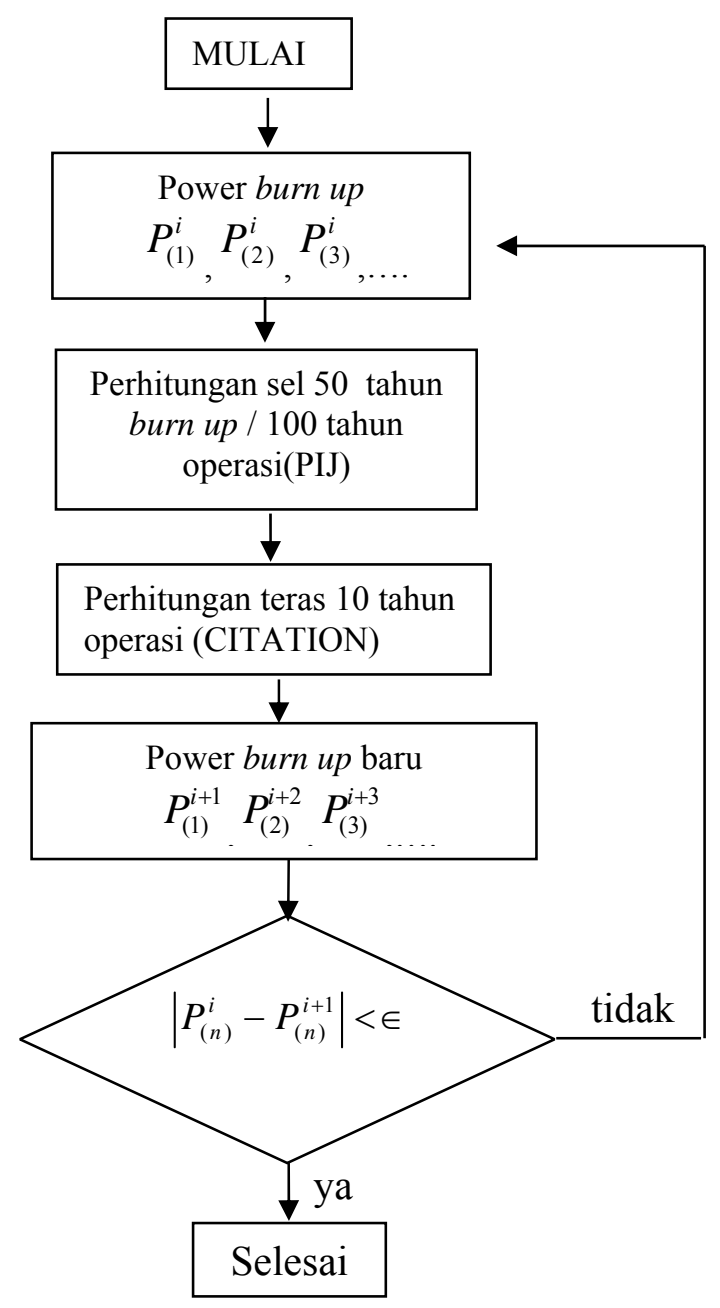

Gambar 5 Flowchart perhitungan.

Dari perhitungan menggunakan sistem kode SRAC, didapatkan hasil untuk rancangan reaktor yang diinginkan. Perhitungan dilakukan dengan cara melakukan iterasi 10 kali sehingga data yang diperoleh konvergen dengan error $<10^{-5}$.

\section{HASIL DAN PEMBAHASAN}

Dengan menggunakan metode perhitungan berdasarkan flowchart pada gambar 5 didapatkan nilai $k_{\text {eff, }} k_{\text {inf }}$ dan parameter lainnya yang menggambarkan kondisi reaktor yang dirancang. Hasil ini dapat di lihat pada gambar 6-10. Dari gambar 6 terlihat bahwa nilai $k_{\text {eff }}$ yang di hasilkan berkisar di atas 1 , hal ini menandakan reaktor yang dirancang berada

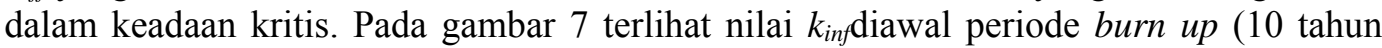


pertama) memiliki nilai kecil dari satu, hal ini disebabkan pada awal periode burn up, densitas bahan bakar fissil (U-235 dan Pu-239) masih kecil. Hal ini berdampak pada jumlah neutron yang dihasilkan di dalam teras reaktor dan menghasilkan nilai faktor multiplikasi di bawah satu. Pada gambar 8 terlihat hubungan antara level burn up dengan periode burn up bahan bakar. Level burn up sebanding dengan periode burn up, dengan naiknya periode burn up jumlah bahan bakar yang diburn semakin besar. Rasio konversi bahan fertil (U-238) menjadi bahan fisil (Pu-239) dapat dilihat pada gambar 9. Analisis burn up bahan bakar menunjukkan densitas U-238 dan U-235 semakin berkurang seiring dengan bertambahnya periode burn upseperti terlihat pada gambar 10 dan gambar 11 . Sedangkan bahan fisil Pu-239 yang awalnya tidak ada menjadi bertambah dengan bertambahnya periode burn upseperti terlihat pada gambar 12 .

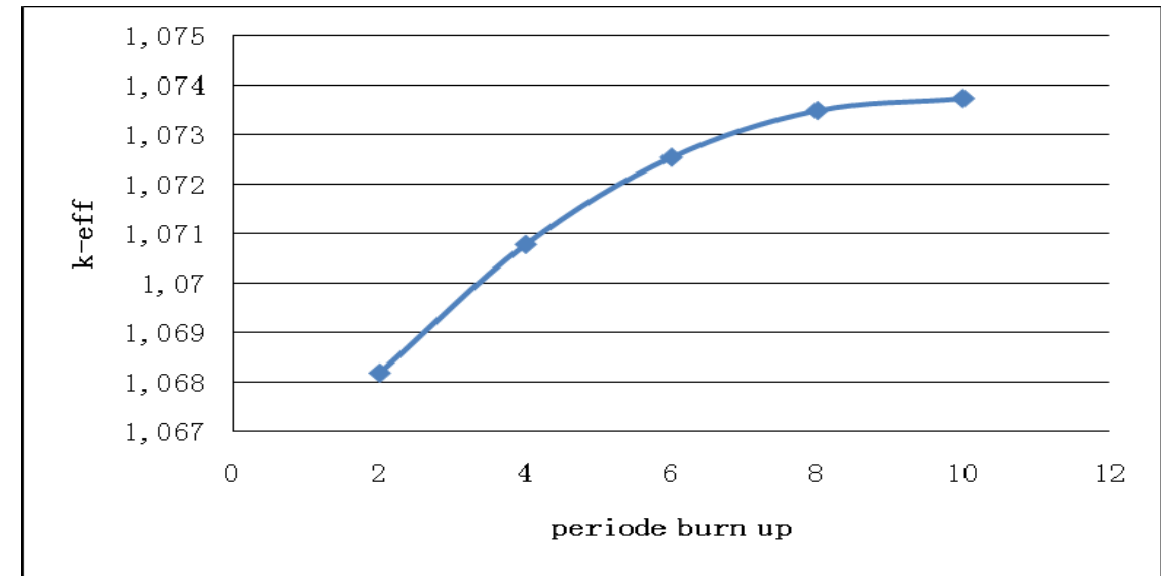

Gambar 6 Grafik hubungan $k_{e f f}$ dengan periode burn up

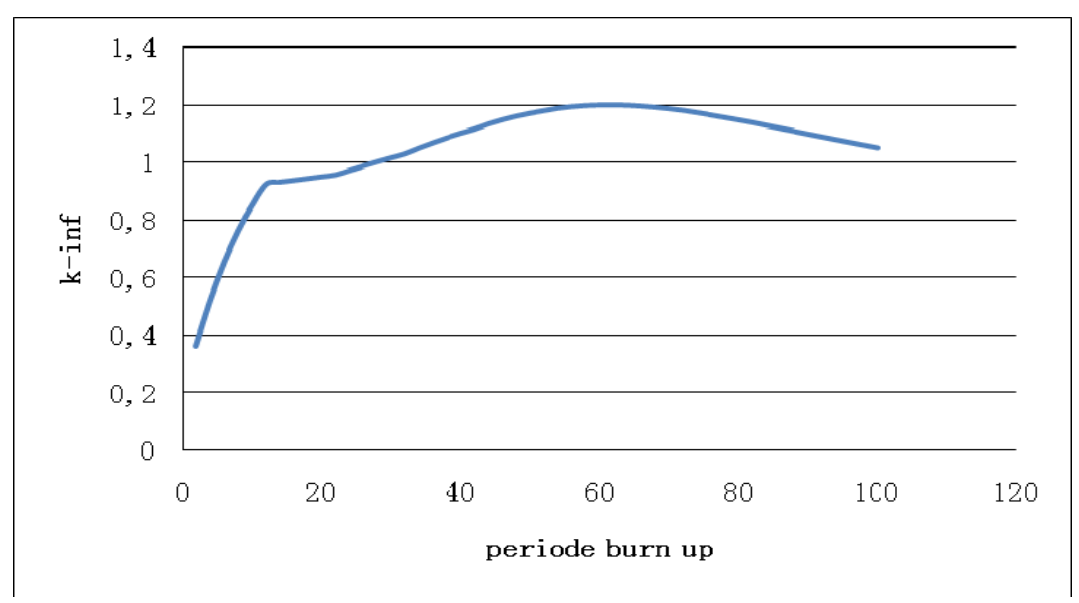

Gambar 7 Hubungan $k_{\text {inf }}$ dengan periode burn up 


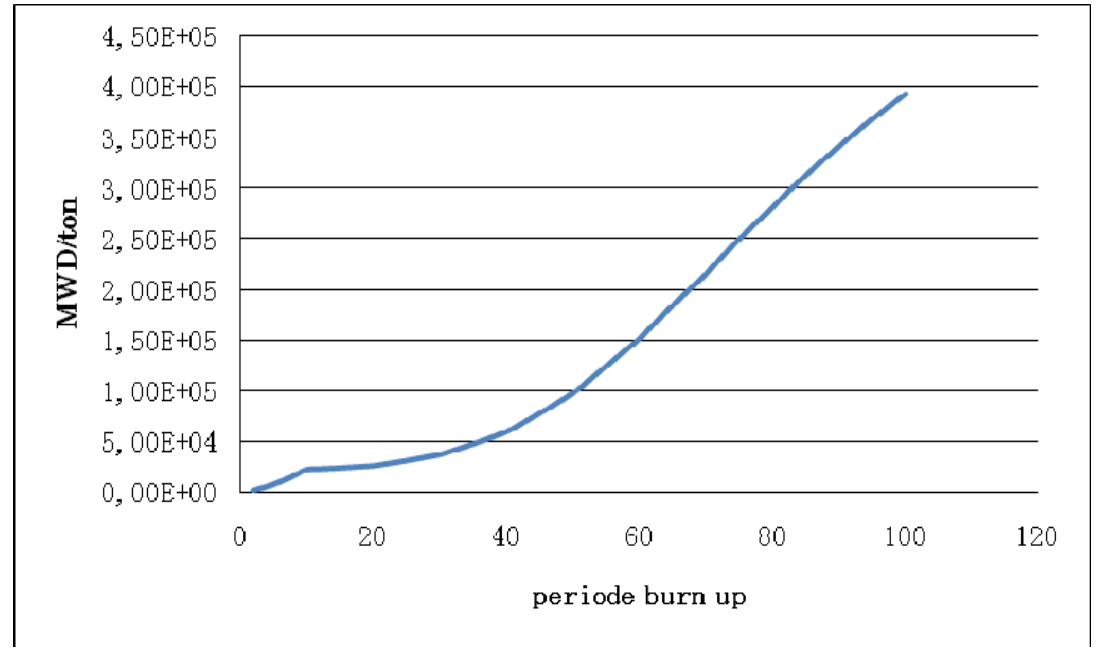

Gambar 8 Level burn up

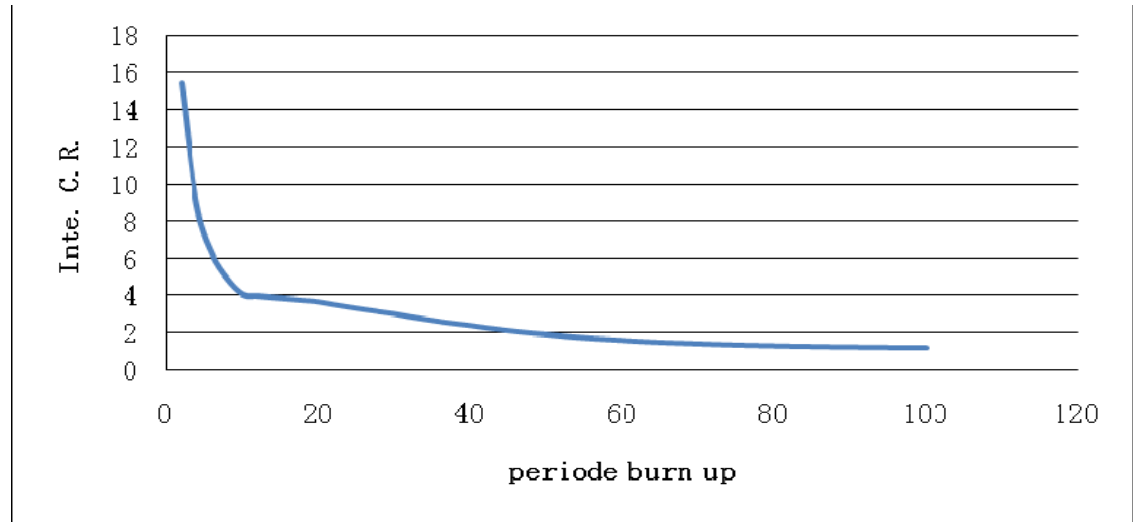

Gambar 9 Rasio konversi U-238 ke

$\mathrm{Pu}-239$

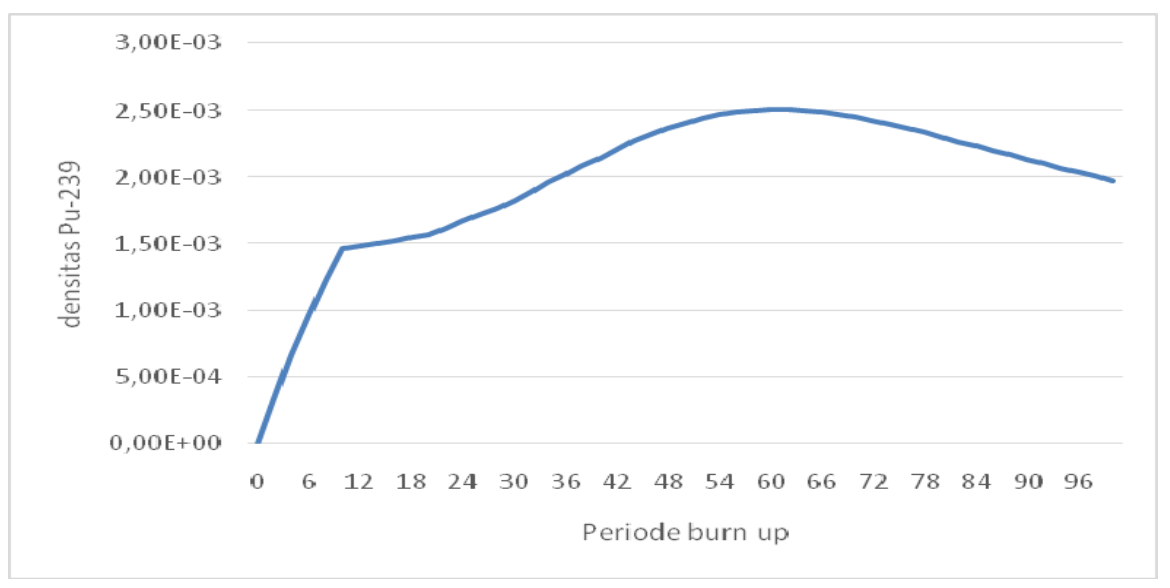

Gambar 10 Densitas atom Pu-239 


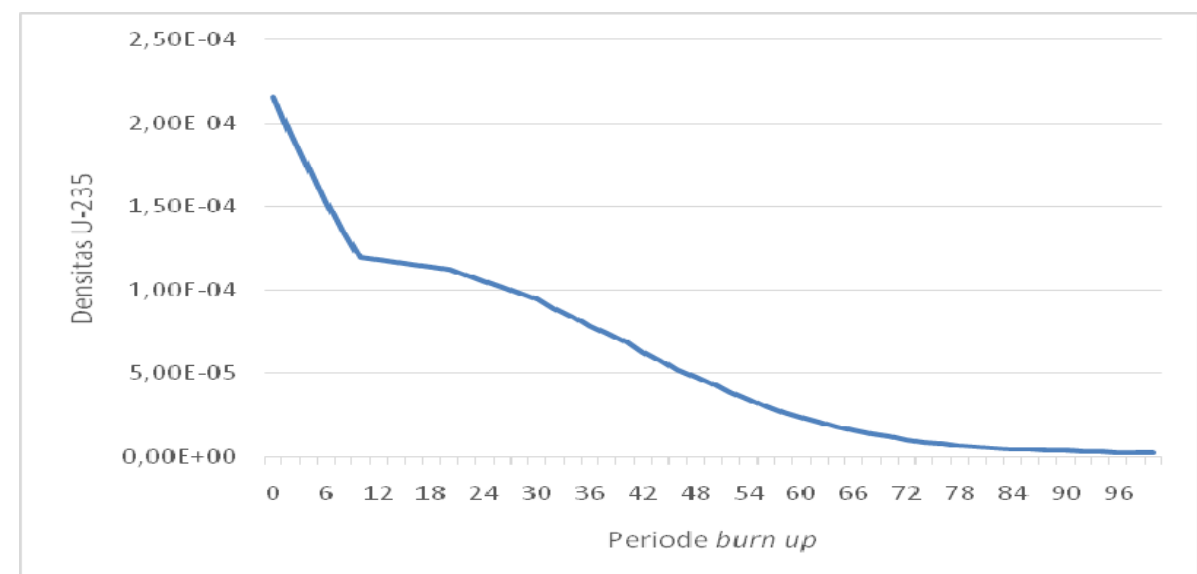

Gambar 11 Densitas atom U-235

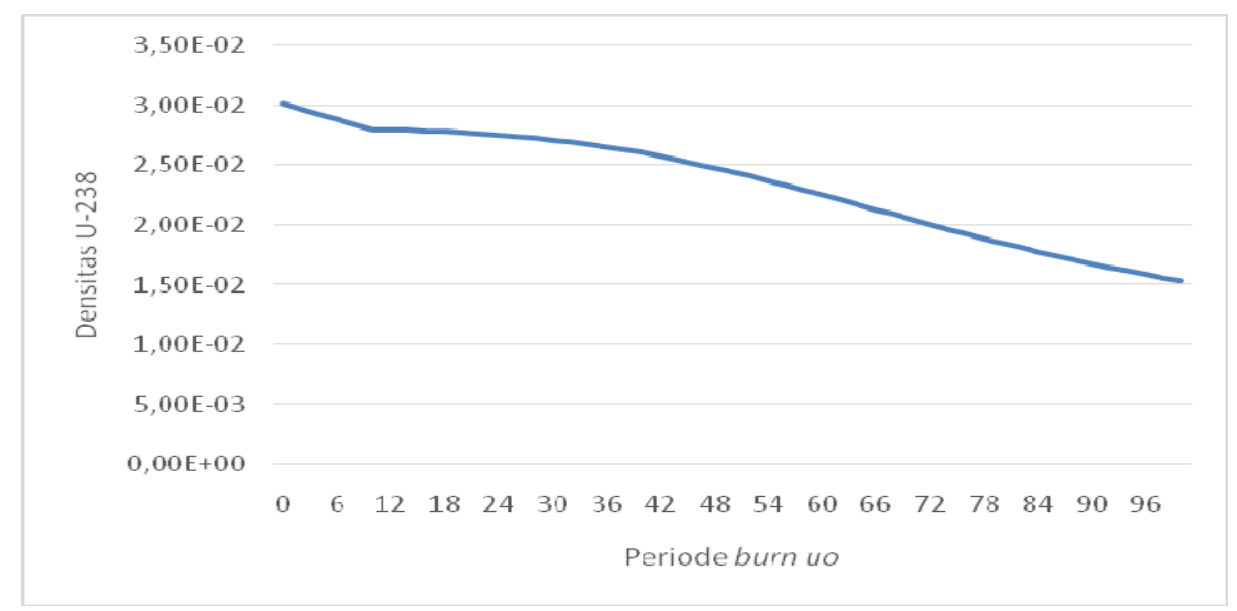

Gambar 12 Densitas atom U-238

\section{KESIMPULAN}

Modifikasi burn up bahan bakar dengan strategi shuffling arah radial memungkinkan reaktor beroperasi menggunakan uranium alam tanpa pengayaan. Hal ini terbukti dengan didapatkannya nilai faktor multiplikasi efektif $\left(k_{e f f}\right)$ lebih dari 1 . Hal ini menandakan reaktor berada dalam keadaan kritis dan dapat dioperasikan. Analisis burn up menunjukkan bahwa densitas bahan bakar fertil (U-238) berkurang seiring dengan bertambahnya periode burn up sebaliknya densitas Pu-239 (bahan fisil) yang di awal periode burn up tidak terdapat di dalam teras reaktor meningkat dengan bertambahnya periode burn up. Hal ini menunjukkan bahwa reaktor cepat menggunakan spektrum neutron cepat yang merubah bahan bakar fertil menjadi bahan bakar fisil.

\section{PUSTAKA}

1. Driscoll, M. J. And P. Heizler, 2005, Reactor Physics Challenges in Gen IV Reactor Design, Nuclear Engineering and Technology, Vol. 27 No. 1, Page 1 - 10

2. Monado, Fiber ; Zaki Su'ud; Abdul Waris; Khairul Basar; Menik Ariani; Hiroshi Sekimoto, 2013, Application of Modified CANDLE Burnup to Very Small Long Life Gas-cooled Fast Reactor. Advanced Material Research Vol. 772 , Page 501-506. Trans Tech Publication, Switzerland 
3. Rida, SNM., 2007, Design Study of Long Life Pb-Bi Cooled Reactors With Natural Uranium as Fuel Cycle Input Using Radial Fuel Shuffling Strategy, International Conference on Advance in Nuclear Science and Engineering in Conjuction with LKSTN 2007, ITB, Page 257-261

4. Waltar, A. E. And Reynolds, A. B., 1981, Fast Breeder Reactor, Pergamon Press, U.S.A.

5. http://www.oektg.at/bildungsarbeit/publikationen/generation-iv-gas-cooled-fastreactor/ 